\title{
Javanese Cultural Socialization in Family and Ethnic Identity Formation of Javanese Adolescent Migrant at Lampung Province
}

\author{
Nina Yudha Aryanti ${ }^{1 凶}$ \\ ${ }^{1}$ Jurusan Ilmu Komunikasi Universitas Lampung, Indonesia \\ Permalink/DOI: http://dx.doi.org/10.15294/komunitas.v7i2.3624 \\ Received : August 2015; Accepted: September 2015; Published: September 2015
}

\begin{abstract}
Javanese adolescent migrants interactions in family across generations at multicultural society in Lampung stimulates a dynamic atmosphere for adolescent ethnic identity formation. Through socialization, the adolescent acquires Javanese cultural information as a foundation to develop their ethnic identity. This research aims are to know, find and analyze the cultural socialization aspects in family that support ethnic identity formation of Javanese adolescent migrants in Lampung. Throughout qualitative research, this research showed that socialization and ethnic identity formation in family is based on six themes: (1) family migration history; (2) adopted and referred family culture; (3) family identity development; (4) parenting style and amount of time spend for interaction in family and parent's type of job; (5) language used within the family; and (6) situations that support and obstruct of expression of ethnic identity.
\end{abstract}

Keywords: socialization; adolescent; Javanese migrant; ethnic identity formation

\section{INTRODUCTION}

Officially, the first migration program of Javanese ethnic to Lampung took place in 1905, during the Dutch colonial period. Through Bedol Desa Program, Javanese people have lived in Lampung for many generations. For many years, Javanese people as part of society have adopted with local ethnic people (Lampungnese) while preserved their own culture.

Javanese people have their own dynamic social aspect to live in multicultural society at migrant area. Some people married with other ethnics. This amalgamation influences the socialization culture in family. In inter- ethnic marriage, parents' (husband-wife) cultural background and domi-

1 Bedol desa program is a migration system presenting movement a group of people that live in a village or a district to other place (other islands that rarely inhibited by people) to distribute people in a country (Indonesia) to increase the development process. It done by Dutch government

Corresponding author:
Address: J1. Soemantro Brojonegoro 1 Bandar Lampung,
$\quad$ Sumatera, Indonesia
Email $\quad$ nina.unila@gmail.com
Telp $\quad: 081273176080$

nation at family will contribute in sharing their origin to their son (or, and daughter). It will be different with the family which husband-wife has the similar culture (Javanese, or intra ethnic marriage). Furthermore, members of both family types interact with others as an individual, or as family member, or as the society's member (Elmhirst 2012; Pruetipibultham 2012).

Family as an initial environment for adolescent has main task to socialize social and cultural values to son (or daughter), in other words family has several functions to help their members to develop their selves. The functions are adaptation, cohesion and communication function (Lam 2009; Meeus 2011; Phinney and Ong 2007; Tartakovsky 2009). Moreover, family also has important roles to [a] help and direct their son (or daughter) to achieve their identity; [b] convey and generate the cultural values to next generation; and $[c]$ to guide the members to

(C) 2015 Semarang State University. All rights reserved p-ISSN 2086 - 5465 | e-ISSN 2460-7320

UNNDS JOURNALS


adapt with the environment. (Jensen, Arthur and Sarah Trenholm 1999, p.281-284; Elmhirst 2011) Adolescent as a part of family and society also need their existence during interaction. They must show their identity, including ethnic identity. Erikson (Hall 2005, p.84) states that "identity formation while beginning in childhood, gains prominence during adolescent. Faced with physical growth, sexual maturation, and impending career choices, adolescent must accomplish the task of integrating their prior experiences and characteristics into stable identity. Further Papalia and Olds (1985, p.452) also states that "the most important task of adolescent is the search for identity, the quest to find out who I really am?" In this case, adolescent with Javanese ethnicity.

Similarly, Pujiriyani (2013, p.153) states that identity reproduction will never be performed on same process and acquired identical result. Each individual has mixed identities without exception. The identities are complex and unique. The most important in determining a person's affinity with a group is the influence from others, especially the influence of the people around him such as family, society members, and other entities. The identity becomes important for someone to show his existence and position in interaction. It's including adolescent identity and their position in the interaction within the family.

In the practice, adolescent as a social being has self-identity in accordance with his role in social interaction. Hall (Samovar 2007, p.112) stated that "each of us has three levels of identity that depending on the context, may or may not salient in our interaction with others. These three levels are personal, relational and communal. Personal are identities those which make you unique and distinct from others. Relational identities are a product of your relationship with people, such as husband/wife, teacher/student, and executive/manager. Communal identities are typically associated with large-scale communities, such as nationality, ethnicity, gender or religious or political affiliation.

Marcia (Desmita 2007, p.217) said that formation identity occurred since children in family interact with other family members. Furthermore, she said that there are several things that influence the formation of identity, are: identification level of parents to their children during childhood and adolescence; parenting style; figure in family; social expectations of identity choice in the family; school and peers; degree of openness of the individual to the alternative identity. Although the identity formation is difficult for adolescents, the stage remains to be passed.

For a long time in migrant area, the second and third generation of Javanese adolescent has been interacting with others. The adolescent who have different cultural background with their ancestor attempts to get their ethnic identity in family and social interaction. Especially in family interaction, the adolescent get their cultural information throughout socialization. The amount of cultural information that adolescent obtained will influence the adolescent ethnic identity formation.

Based on the description above, this article investigates how Javanese cultural socialization supports formation of ethnic identity in Javanese adolescent migrant at Lampung Province. Furthermore, this study is aimed to get an explanation and analysis of ethnic identity formation of Javanese adolescent migrant at Lampung Province. This study is important in the way it explores identity formation among migrant adolescents. The existing studies on identity migration largely do not focus on the identity formation among the adolescents (Crocetti, Rubini and Meeus 2008; Elmhirst 2011; Feliciano 2009; Lam 2009; Meeus 2011; Phinney and Ong 2007; Pruetipibultham 2012; Tartakovsky, 2009).

\section{RESEARCH METHOD}

This study is a qualitative research focused on how the Javanese adolescent migrants form their ethnic identity through cultural socialization in the family.

Lampung Province as a research location is chosen based on several reasons: (1) Javanese has been adapted to many Lampung ethnics for many generations; (2) 
some families have moved from one district to others in Lampung Province; it is positioning the adolescent at some diverse interaction settings; (3) The adolescent family with local migration as a background give a different experience in social and cultural adaptation. This condition affects the knowledge and understanding of the family to Javanese culture that are being socialized to adolescent as a family generation. Next, this research was conducted in Ketapang, South Lampung district, Lampung Province.

Subjects were selected purposively, with criteria as follow: (1) adolescent with Javanese migrant background; (2) adolescent who has one or both Javanese parents; (3) adolescent family is in multi-ethnic environment. Furthermore, subjects include both parents (the nuclear family) and others who live at home (the extended family).

This study required data from participant observation, supported by in-depth interviews and documentation of adolescent ethnic identity formation and socialization in family. Data processing and analysis was done by data reduction, data presentation and data verification (Moleong 2005, p.288). Then, the data validity was conducted through observation perseverance, an extension of time of observation and triangulation (Birowo 2004, p.5-8).

\section{RESULTS AND DISCUSSION}

The research showed that adolescent ethnic identity was developing based on family socialization. It's based on six themes, are: (1) family migration history; (2) adopted and referred family culture; (3) family identity development; (4) parenting style, quality time spent with family and the father's type of job; (5) language used in the family; and (6) the situations that support and hinder of expression of ethnic identity.

\section{Family migration history}

Migration history of family was influenced the family knowledge and experience in adopting and adapting family cultural. The family migration history related with the composition of the family members, either as a nuclear family or extended family. The composition of the members of the family (nuclear family or conjugal) affected the socialization process and cultural adoption of the family. It was also associated with the position of the adolescent generation. The second-generation adolescents are usually in the nuclear family, and the third-generation adolescents are in an extended family.

The first generations migrated to Lampung were born at Java Island and they knew Javanese culture better than they who were born at Lampung. They were grandmother - grandfather of the adolescent at third generation or parent of the second generation. Furthermore, Javanese people at Lampung have two categories, they are: (1) extended family with three members: grandfathergrandmother as first generation; parents as second generation and the adolescent as third generation. At extended family, both parents and adolescent were born at Lampung and acquired Javanese cultural information from parents and others Javanese communities. (2) Nuclear family has two members: parents as first generation and the adolescent as second generation.

At extended family grandparents was born at Javanese island, parents and the adolescent born at Lampung. At nuclear family; parents were born at Javanese Island and the adolescent were born at Lampung. Aside from differences in generation level, they also have differences at cultural experiences. One who was born at Java Island has cultural experience direct from the native society. Others were born at Lampung have Javanese cultural experience from the Javanese migrate society.

It shows that generation level and experience of family migration effected the acquisition of Javanese culture in parents; but none was found on adolescent.

Adolescent's cultural information will support their ethnic identity development. It was deal with two things, they were: (1) the duration of time of their family living in migrant area, especially the ancestor, someone who first time went to Lampung and interacted with others. Then, (2) intensive level of their family communication related to the frequency of meeting, adolescent 
closeness with parents (or grandparents, for adolescent at third generation) and qualified time spent with family.

\section{Adopted and referred family culture}

The adolescent learnt about the various social roles from socialization in family interaction. The direct learning was done when adolescent have their own experience that obtained from parent or other family members (Umaña-Taylor Bhanot and Shin 2006). This is done through sharing of cultural value that involve adolescent in it. Indirect cultural learning was done when the adolescent obtained cultural information from others, not by their own experience.

The adolescent knowledge and experience of culture based on cultural that adopted and referred by the family. The research shows that there are three cultural values that family adopted and referred to. They are Javanese cultural, non-Javanese as a culture of one of the parents and combination of both parents cultural and society cultures.

The family adaptation mingled with external environment influenced ethnocentrism and stereotypes cultural. The Javanese cultural ethnocentrisms supported the adolescent to improve their cultural competencies, but in other side, the adolescent tend to avoid attitude and behavior that expressed stereotypes. Rochana (2012, p.607) stated that ethnocentrism and stereotypes in Lampung province is influenced by three factors, namely socio cultural factors, settlement patterns and the type of family marriage. Socio cultural factors refer to the domination of social and cultural society. Settlement patterns deal with the ethnicity neighborhood. Family with Javanese neighbors tends to be more solid to develop a culture of Java in the family. The family with non Javanese neighbors tends to be more egalitarian in developing family culture. The marriage types referred to adolescent's parent ethnicity. In addition, how families adapted their culture will provide an experience and reference for the adolescent to develop their ethnic identity.

\section{Family identity development}

The ethnic identity development has various dynamic. Some adolescent did not refer their father ethnic identity, although they have patriarchy system. This research showed that adolescent ethnic identity formation and development depended on degree of relationship between parents and son/ daughter. This is reflected by the qualified time spent together with family and relationship quality that reflected parenting and family communication.

As a part of family and society; the adolescent ethnic identity development cannot be separated from cultural family identity. Adolescent will refer the family interaction pattern and apply it in social interaction. The family cultural value will guide the adolescent to take place on their social interaction. The way they view the society is based on the family views of society.

The dynamics interaction of the adolescent within family reflected that the adolescent as an individual who is active in processing the message. Commonly, they want to be Javanese. Although they have Javanese cultural knowledge and experience in minimum stage, they try to get this ethnic identity by reconstruct their Javanese cultural references to support their ethnic identity formation. The cultural family identity reflected on the adolescent ethnic identity. This cultural will affect the dynamic interaction of adolescent in society.

\section{Parenting, qualified time spent with family and father's type of job} In particular, the dynamics of interaction and Javanese culture socialization in the family is dealing with parent ethnicity and family parenting style. The results showed that adolescent's parents have two types of parenting style; they are democratic and permissive style. They tend to refer the Javanese culture at democratic parenting style, while they who are in a permissive parenting style tend to choose both parents cultures (Javanese-non Javanese).

At democratic parenting style, the adolescent have positive support to be more confident to develop their self, so the ado- 
lescent can explore their social role in family comfortably.

They are the second generation who both parent are Javanese and tend to choose Javanese as their ethnic identity. They whose parents have different cultural identity as third generation also tend to chose Javanese as their ethnic identity. These third generations get Javanese cultural information from their grandmother and grandfather that lived around them. It's showed that if the third generation adolescent didn't get more qualified time with their parents, they get it from their grandparents.

At permissive parenting style, the adolescent tend to refer cultural from both parents. In amalgamation, the adolescent get both parents' cultural information. Although they have two cultural experiences, the Javanese cultural was dominant family culture. This conditions supported by the parents jobs. The research showed that the Javanese father jobs are therapist and farmer; so he has more qualified with family. In other sides, the non-Javanese father's jobs are coconut collectors, traders and casual laborers; so the he hasn't more qualified time with family.

The adolescent father's job also related with the availability of family time. Some fathers have much time in family interaction, others haven't. Furthermore, this conditions effect on the degree of father-son/daughter relationship. Adolescents tend to be close to the father's cultures when the father has more me time with the family or they tend to understand the mother's cultures if the father often worked outside for a long time or. It's showed that parenting supports by qualified time with family were important in family cultural socialization process.

\section{The language that used in the family}

Based on interview, adolescents stated that ethnic identity of adolescent Javanese migrant can be identified from their language in interaction. Most of them said that if they want to be Javanese, they must speak in Javanese, although with limited vocabularies. Additionally, the research showed that Javanese language skill is not related with the adolescent generation level; but with daily language used in family interaction. The Javanese language is verbal and non verbal language, so the adolescent must master both skills.

In general, the Java language consists of three levels. They are (1) Krama Inggil (The highest level of Javanese language) is verbal communication which insists its users to talk softly with self restraint; (2) Krama Madya (The middle level of Javanese language) is verbal communication which inquires its users to talk softly with self restraint but not as strict as karma inggil; and (3) Ngoko (The lowest level of Javanese language) with straightforward verbal communication. Based on these categories, almost all adolescent use Ngoko to communicate. The adolescent of third generation speak Ngoko softly with self-restraint. Next, the adolescent of second generation speak Ngoko with straightforward verbal cues. In generally, they use Ngoko when they speak with someone who they address as Javanese or someone who knows Javanese language. In other interactions, they use Indonesian as a national language.

\section{The situations that support and hinder of expression of ethnic identity}

Commonly, there are two situations in family interaction, comfortable and uncomfortable situations.

In comfortable situation during family interaction, the adolescent can express well about their selves and identity. They can improve their ability to gain the ideal self as a son, daughter, and other identities that they want to.

Uncomfortable situation occurs when they confuse to stand during family interaction. They have various responses are (1) the adolescent who speak straightforward Ngoko will respond passively or ignore it; and (2) the adolescent who speak Javanese softly with self restraint tend to be quiet in interaction. The uncomfortable situation in family interaction is when they behave incompatible with Javanese cultural and have "Lampung" as labeling. They want to be Javanese and others think them like that, so 
they will behave like Javanese.

Although the adolescent are on uncomfortable interaction situation, they never leave it. The social force of family put the adolescents in a situation which demand them to obey the rules, become obedient and respectful to parents. This situation attempts the adolescent at a weak bargaining position under parent's authority as a family leader.

\section{DISCUSION}

Based on the explanation above, this research states that there are three classified identity frameworks that involve the family cultural socialization to support ethnic identity formation of the adolescent Javanese migrants. They are personal, relational and social framework. This research result is parallel with Hall idea (samovar 2007, p.112), as mentioned earlier.

\section{Personal framework}

In the framework of personal / individual scope, adolescent ethnic identity is shaped and influenced by motives, motivation, competence, communication goals, include the self-development goal to ideal self. In this framework, the adolescent also involved their personal views from their self concept. The adolescent ethnic identity formation in this framework is derived from their consciousness to self projection in interaction, so ethnic identity is a source of hope and motivation of adolescent in interaction in the family. Their ability to process several of cultural information will differentiate their ethnic identity with others.

At identity formation, the adolescent tend to be confused in expressing or interpreting their ethnic identity. Looking at the condition through psychology adolescent process, they are in process to find self concept, and they aware that they need the identity in social interaction. In this case, the adolescent need others to compare their self meaning to create their identity.

In this research, the adolescent tried to gain the Javanese identity. With minimum experience and knowledge on Javanese cultural complexity, they reduced the cultural criteria to gain their ethnic identity. Most of adolescent said that if they want to be Javanese, they must speak Javanese language. They ignored other Javanese cultural, because they did not know about them well. Most of them said that Javanese cultures have many rules, complicated, deal with myth and rituals. They also said that Javanese cultural is ancient and not modern, so it was difficult for them to explain and understand it. Some of them said that they join in the cultural ritual without understanding its meaning.

They tend to be Javanese because: (1) they feel comfortable to be Javanese; (2) they have more Javanese cultural information than others; (3) Javanese is the major population at Lampung so easier to them to get social acceptance.

\section{Relational Framework}

Identity is a personal message in interaction. It is emerged as a part of relation at interaction with others. Individual have many identies when they interact with others. They can be son, friend, partner, etc; depending on relational themes and interactional contexts. The relationship types will influence the personal roles that play at interaction.

At family relational, adolescent position is a son, or daughter; or grandchild have a roles as his position in interaction. They establish, develop and adapt their ethnic identity in family interaction. They develop themselves and their experience based on self-projection of experience of the past, now and the future (the ideal/ hope of self).

At relational framework, the ethnic identity formation deals with view and social recognition of self reciprocally that suits the theme and contexts of relationships. This relational framework relates to personal framework of them who involved in the communication process. Furthermore, by verbal and nonverbal language in interaction, the adolescent will be able to mediate their selves with the environment. Then adolescent will take social role based on their views and self-assessment to perceive and assess others, so by taking role, the adolescent will connect themselves with others 
and environment.

In relationship, the adolescent will interpret objects and situations around which are related to the physical context of the communication. Whereas, in responding to the relationships context, they will look back to their interaction history. They will direct and control their attitude and behavior by the social interaction messages.

In the framework of the relationship, the individual cannot be separated from their identification of the position and role in the interaction. It is also related to the cultural and social context that covers on the ongoing interaction. Further, Dood (1998, p.39-40) state that "member every culture have a sense of social identification: who they are and why. In other words, cultures can be linked to a group personality... One's cultural identity affects interpersonal relationship and expectations of individual activity. From a sense of social identity (who we are, one receives a sense of personal identity (who I am)".

\section{Social framework}

The adolescent ethnic identity formations are connected to personal identity, relational identity and social identity. It cannot be separated one by one. Sometimes all identities blend in a social interaction. Although they have interaction with the same people, but they are in various themes and interaction contexts that ask them to show different identity based on their role in interaction. The adolescent need the ethnic identity of Javanese transmigrants to establish and to gain barganining position in social interaction.

The adolescent referred the Javanese cultural of family and neighborhoods to establish and develop their ethnic identity in their social interactions. Tajfel (in Gudykunts 2004, p.77) said that social identities are those part of an individual's self-concept which derives from his [or her] membership in a social group (or groups) together with the value and emotional significance attached to that membership. Specifically, the social framework of ethnic identity was deal with social identities that based on cultural groups. The adolescent refer cultural attribute to develop their ethnic identity.

At the social framework, the formation and development of ethnic identity adolescent based on their knowledge and experience in the relation on inter-individual and inter-family, so both of it will guide to get communal consciousness that develop in society. The difference in knowledge, experience and understanding of adolescent in family and society affect the values that built and developed in interaction. Furthermore, individuals, families and society will adapt to each other to reach their desire and goal in developing a culture. Agreements culture built together will determine the dynamics of the development of culture and identity in the community. The communal cultures that built together will determine the dynamics of the development of culture and identity in the community.

\section{CONCLUSION}

In general, the family as the first environment of adolescent has important role in the formation of ethnic identity. By socialization, the adolescent will get much cultural information that supported the adolescent to form their ethnic identity. Specifically, the Javanese ethnic identity in Lampung province related with Javanese culture groups that live across generation. In the context of this study, a Javanese culture group is the nuclear family and/or extended family that husband-wife (or adolescent parents) that one or both of Javanese.

Javanese cultural socialization in the family and adolescent ethnic identity formation Javanese migrants based on six themes, are: (1) family migration history; (2) adopted and referred family culture; (3) family identity development; (4) parenting, family time and fathers' types of job; (5) language used in the family; and (6) situations that support and hinder of expression of ethnic identity. Furthermore the results of Javanese cultural socialization in the family will guide adolescent to form the Javanese ethnic identity at personal/individual, relational and social level. 


\section{REFERENCES}

Birowo, A., 2004. Metode Penelitian Komunikasi. Gitanyali, Jogjakarta.

Desmita. 2007. Psikologi Perkembangan. Remaja Rosda Karya, Bandung.

Dood, C.H., 1998. Dynamics of intercultural communication, Fifth edition. Mc Graw Hill, Boston.

Elmhirst, R., 2011. Migrant pathways to resource access in Lampung's political forest: Gender, citizenship and creative conjugality. Geoforum, 42(2), pp.173-183.

Elmhirst, R., 2012. Displacement, resettlement, and multi-local livelihoods: Positioning migrant legitimacy in Lampung, Indonesia. Critical Asian Studies, 44(1), pp.131-152.

Gudykunts, W.B., 2004. Bridging Differences: Effective Intergroup Communication $4^{\text {th }}$ Edition. Sage Publication, California.

Hall, L.E., 2005. Dictionary of Multicultural Psychology: Issues, Term, and Concept. Sage Publication Inc., California.

Jensen, A., Sarah, T., 1999. Interpersonal Communication $3^{\text {th }}$ Edition. Wadsworth Publishing Company, USA.

Lam, W.S.E., 2009. Multiliteracies on instant messaging in negotiating local, translocal, and transnational affiliations: A case of an adolescent immigrant. Reading Research Quarterly, 44(4), pp.377-397.

Meeus, W., 2011. The study of adolescent identity formation 2000-2010: A review of longitudinal research. Journal of research on adolescence, 21(1), pp.75-94.

Moleong. L.J., 2005. Metode Penelitian Kualitatif. Remaja Rosda Karya, Bandung.
Papalia, D.E., Sally, W.O. 1985. Psychology. Mc. Graw Hill, USA.

Phinney, J.S. and Ong, A.D., 2007. Conceptualization and measurement of ethnic identity: Current status and future directions. Journal of Counseling Psychology, 54(3), p.271.

Pruetipibultham, O., 2012. Developing human resource development interventions to aid expatriates' cultural adaptation: insights to the Javanese culture. Human Resource Development International, 15(1), pp.109-117.

Pujiriyani. 2013. Re-Imajinasi Ke-Indonesia-an dalam Konteks Network Society. Jurnal Komunitas, 5(2), pp.153.

Rochana E., Nina, N.A. 2012. Etnosentrisme dan Stereotip dalam Dinamika Interaksi Antaretnik di Propinsi Lampung. in Prosiding Seminar Hasil Penelitian dan Pengabdian Masyarakat Universitas Lampung. Penerbit Lemlit Unila, Bandar Lampung.

Rogers, E.M.; Thomas M.s. 1999. Intercultural Communication. Waveland Press Inc, Illinois.

Samovar, L.A., Richard E.P. and Edwin R.Mc.D., 2007. Communication between Cultures. Sixth Edition. Wadsworth, California.

Segrin, C., Jeanne, F., 2005. Family Communication. Lawrence Erlbaum Associates Publisher, London.

Tartakovsky, E., 2009. Cultural identities of adolescent immigrants: A three-year longitudinal study including the pre-migration period. Journal of Youth and Adolescence, 38(5), pp.654-671.

Umaña-Taylor, A.J., Bhanot, R. and Shin, N., 2006. Ethnic identity formation during adolescence: The critical role of families. Journal of Family Issues, 27(3), pp.390-414. 